\title{
Attitudes and Perceptions of Healthcare Professionals towards Pharmaceutical Care Services in Kingdom of Saudi Arabia
}

\author{
Yousef Ahmed Alomi ${ }^{1, *}$ (D, Ban Abdullah Aldosary ${ }^{2}$, Sarah Abdullah Al-Hathlool ${ }^{3}$, Maryam Ibrahim \\ Almulhim $^{3}$, Amal Ali Alashaq ${ }^{3}$, Yousef Aboshalaf ${ }^{4}$, Mytham Al-Ethan ${ }^{4}$ \\ ${ }^{1}$ The Former General Manager of General Administration of Pharmaceutical Care, Former Head, National Clinical \\ Pharmacy and Pharmacy Practice, Former Head, Pharmacy R and D Administration, Ministry of Health, Riyadh, \\ SAUDI ARABIA. \\ ${ }^{2}$ Pharmaceutical Care Department, Al-Amel Mental City, Ministry of Health, Riyadh, SAUDI ARABIA. \\ ${ }^{3}$ Clinical Pharmacy Staff Ministry of Health, Riyadh, SAUDI ARABIA. \\ ${ }^{4}$ Head of Pharmacy Services King Fahad Hospital, Alhasa Health Affairs, Alhasa, SAUDI ARABIA.
}

\begin{abstract}
Objective: Pharmaceutical care is a health science discipline in which pharmacists deliver patient care that improves medication therapy and helps health, wellness and disease prevention. An important issue in this area emphases on patient oriented rather than drug product-oriented service. The aim of this study to evaluate the attitudes and perceptions of health care professionals towards Pharmaceutical care services in Kingdom of Saudi Arabia. Methods: A 4-months cross-sectional survey of healthcare professionals was conducted in Kingdom of Saudi Arabia. The survey consisted of two-part demographic information and second part forty-nine questions divided into four domains. It included domain one: It included domain one: Primary or essential information about healthcare providers pharmacists, domain two: healthcare professionals information about the ambulatory care pharmacy, domain three: healthcare professionals information about pharmacist's relationship and counseling and domain four: Healthcare providers perception of Pharmaceutical care services. All type of healthcare professionals included in the study. A 5-point Likert-type scale was used. There were open and closed-ended questions. The survey was distributed through social media by using what's App to more than one thousand healthcare professionals overall Kingdom of Saudi Arabia. The survey was made in an electronic format and it analyzed domain two: healthcare professional's information about Pharmaceutical care services through survey monkey system. Results: The total responders were 170 healthcare providers. Of those 150 (93.8\%) were Saudi and 10 (6.25\%) were non-Saudi. The gender distribution 129 (75.9\%) were females and 41 (24.1\%) were males. The most of the healthcare professionals were pharmacists $81(47.65 \%)$, followed by nurses 27 (15.88\%) and physicians $23(13.53 \%)$. The majority of patient had visited a pharmacy more than 10 times in the past 12-months was $53(31.36 \%)$, while 40 (23.67\%) of respondents visited a pharmacy more than 5 to 9 times. The most common performances of pharmaceutical care services were dispensing of prescribed medication 119 (73.91\%), medication consultation $89(55.28 \%)$, dispensing of over the counter medications 88 (54.66\%) and dispensing of non-medications supplements 74 (45.96\%). The highest scores of pharmaceutical care services provides to the patients were at private's hospitals (3.45) and non-MOH governmental hospitals (3.40). The most current experience of perception and challenges with high propriety scores were few pharmacist and clinical pharmacists, un-available of patient medication counseling privacy and Unclear handwriting prescription. The most Future Perception suggestion with high Propriety and Opportunity scores were Increase awareness of pharmacist role in public health and Implement patient counseling clinic operated by the pharmacy. Conclusion: Healthcare professional's insight is the dynamic tool to develop pharmacy services. Increase the number of the clinical pharmacist, expand the awareness of pharmacist to the public and implement patient counseling clinic, will change the future vision of pharmacy career in Saudi Arabia.

Key words: Attitudes, Perceptions, Healthcare Professionals, Pharmaceutical Care, Saudi Arabia.
\end{abstract}

Received: 20-12-2018;

Accepted: 29-02-2019

*Correspondence to:

Dr. Yousef Ahmed Alomi

The Former General Manager of Genera Administration of Pharmaceutical Care, Former Head, National Clinical Pharmacy and Pharmacy Practice, Former Head, Pharmacy R and D Administration, Ministry of Health, P.O.BOX 100, Riyadh 11392, Riyadh, SAUDI ARABIA.

Phone no: +966 504417712

Email: yalomi@gmail.com

DOI: $10.5530 /$ ijpcs.2019.8.19

Copyright: @ the author(s),publisher and licensee International Journal of Pharmacology and Clinical Sciences. This is an open-access article distributed under the terms of the Creative Commons Attribution Non-Commercial License, which permits unrestricted noncommercial use, distribution, and reproduction in any medium, provided the original work is properly cited.

This is an open access article distributed under the terms of the Creative Commons Attribution-NonCommercial-ShareAlike 4.0 License

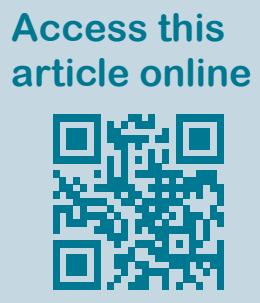

www.ijpcs.net 


\section{INTRODUCTION}

The main role of pharmacy was and will remain to be dispensing medications. The distinctive role of clinical pharmacists through pharmaceutical care services includes ensuring appropriate prescription and administration of the precise medicine to the right patient in the suitable dose through the appropriate route of administration. In addition, clinical pharmacist is to monitor patient observance to therapy, provide drug information and monitor patient responses and laboratory values and provider education. All the healthcare professionals have diverse knowledge of drug information and permission of their specialties. ${ }^{[1-3]}$ The physicians' emphasis on prescribing medications and write the medications properly. The pharmacist's concern about how to prepare the medications and allot the medications. While the nurse's consent of medications administration and transcription.

All pharmacy organizations over all the world founded several elements to corporate with healthcare professionals including physician, nurses and pharmacists. The collaboration and cooperation's skills are requiring to work as a medical team inside healthcare institution. The collaboration between physician, nurse and pharmacist improve patient clinical outcome and diminution the economic burden on the healthcare system. ${ }^{[1-3]}$ However, the healthcare professional's feedback, suggestion and opinion are essential to provide the best care to the patients. ${ }^{[4,5]}$ Accomplishing therapeutic effectiveness and optimal outcomes for patients getting some drugs remains complex. It often a challenge for pharmacists and other healthcare professionals. Few studies investigated the healthcare professional's perception of pharmaceutical care services with significant variation among patient and healthcare providers. ${ }^{[6,7]}$ Healthcare providers play the vital role in permitting patients with the essential skills and knowledge of perception medication. Most of the studies engrossed on particular specialty, not a common perception. It is hard to find local in Gulf or Middle East counties. The goal of this study was to explore the healthcare professional's perception of the pharmaceutical care services in the Kingdom of Saudi Arabia.

\section{METHODS}

A 4-months cross-sectional survey of healthcare professionals was conducted in Kingdom of Saudi Arabia. The survey consisted of two-part demographic information and second part forty-nine questions divided into four domains. It included domain one: It included domain one: Primary or essential information about healthcare providers pharmacists, domain two: healthcare professionals information about the ambulatory care pharmacy, domain three: healthcare professionals information about pharmacist's relationship and counseling and domain four: Healthcare providers perception of Pharmaceutical care services. All type of healthcare professionals included in the study. A 5-point Likert-type scale was used. There were open and closed-ended questions. The propriety and opportunities scores of 5-point scales was used for the current, future perception and challenges. The survey was distributed through social media by using what's App to more than one thousand healthcare professionals overall Kingdom of Saudi Arabia. A message reminder was sent to healthcare professional after two weeks and additional message reminder was sent to healthcare professional after four weeks. The survey was made in an electronic format and it analyzed domain two: healthcare professional's information about Pharmaceutical care services through survey monkey system.

\section{RESULTS}

The total responders were 170 healthcare providers. Of those 150 (93.8\%) were Saudi and 10 (6.25\%) were non-Saudi. The gender distribution 129 (75.9\%) were females and $41(24.1 \%)$ were males. The majority of them in age (18-44) 95.8\% and located at East Province region $36(21.7 \%)$, Alhasa region $26(15.66 \%)$ and Riyadh region 69 (41.6\%). The most of the healthcare professionals were pharmacists $81(47.65 \%)$, followed by nurses 27 (15.88\%) and physicians 23 (13.53\%). The most responders had the Bachelor Degree 126 (76.4\%) followed by Diploma 16 (9.7\%) and Master degree $8(4.85 \%)$. The majority of patient had visited a pharmacy more than 10 times in the past 12 -months was $53(31.36 \%)$, while $40(23.67 \%)$ of respondents visited a pharmacy more than 5 to 9 times. The majority of healthcare professional had visited the pharmacy at evening 79 (47.31\%) and morning $54(32.34 \%)$ (Table 1). The most common activities of pharmaceutical care services were dispensing of prescribed medication 119 (73.91\%), medication consultation 89 (55.28\%), dispensing of over the counter medications 88 (54.66\%) and dispensing of non-medications supplements 74 (45.96\%) (Table 2). The highest scores level of pharmaceutical care services were at private's hospitals (3.45) and non-MOH governmental hospitals (3.40) 


\begin{tabular}{|c|c|c|}
\hline & $\begin{array}{l}\text { Response } \\
\text { Count }\end{array}$ & $\begin{array}{l}\text { Response } \\
\text { Percent }\end{array}$ \\
\hline \multicolumn{3}{|l|}{ Sex } \\
\hline Female & 129 & $75.9 \%$ \\
\hline Male & 41 & $24.1 \%$ \\
\hline Answered question & 170 & \\
\hline Skipped question & 0 & \\
\hline \multicolumn{3}{|l|}{ Nationality } \\
\hline Saudi & 150 & $93.75 \%$ \\
\hline Non-Saudi & 10 & $6.25 \%$ \\
\hline Answered question & 160 & \\
\hline Skipped question & 10 & \\
\hline \multicolumn{3}{|l|}{ Age } \\
\hline$<18$ & 0 & $0.00 \%$ \\
\hline $18-29$ & 127 & $75.60 \%$ \\
\hline $30-44$ & 34 & $20.24 \%$ \\
\hline $45-59$ & 7 & $4.17 \%$ \\
\hline $60+$ & 0 & $0.00 \%$ \\
\hline Answered question & 168 & \\
\hline Skipped question & 2 & \\
\hline Type of visit & $\begin{array}{l}\text { Response } \\
\text { Count }\end{array}$ & $\begin{array}{l}\text { Response } \\
\text { Percent } \\
\end{array}$ \\
\hline Physician & 23 & $13.53 \%$ \\
\hline Dentist & 4 & $2.35 \%$ \\
\hline Pharmacist & 81 & $47.65 \%$ \\
\hline Nurse & 27 & $15.88 \%$ \\
\hline Others & 33 & $19.41 \%$ \\
\hline Answered question & 170 & \\
\hline Skipped question & 0 & \\
\hline $\begin{array}{l}\text { In the last } 12 \text { months, the number of } \\
\text { times visited the pharmacy }\end{array}$ & $\begin{array}{l}\text { Response } \\
\text { Count }\end{array}$ & $\begin{array}{l}\text { Response } \\
\text { Percent }\end{array}$ \\
\hline None & 6 & $3.55 \%$ \\
\hline 1 time & 15 & $8.88 \%$ \\
\hline 2 & 21 & $12.43 \%$ \\
\hline 3 & 19 & $11.24 \%$ \\
\hline 4 & 15 & $8.88 \%$ \\
\hline 5 to 9 & 40 & $23.67 \%$ \\
\hline 10 or more times & 53 & $31.36 \%$ \\
\hline Answered question & 169 & \\
\hline Skipped question & 1 & \\
\hline Time of Visiting the Pharmacy & $\begin{array}{l}\text { Response } \\
\text { Count }\end{array}$ & $\begin{array}{l}\text { Response } \\
\text { Percent } \\
\end{array}$ \\
\hline Morning & 54 & $32.34 \%$ \\
\hline Evening & 79 & $47.31 \%$ \\
\hline Night & 34 & $20.36 \%$ \\
\hline Answered question & 167 & \\
\hline Skipped question & 3 & \\
\hline $\begin{array}{l}\text { The waiting time to get the } \\
\text { medications }\end{array}$ & $\begin{array}{l}\text { Response } \\
\text { Count }\end{array}$ & $\begin{array}{l}\text { Response } \\
\text { Percent }\end{array}$ \\
\hline$<5$ & 70 & $42.68 \%$ \\
\hline $5-10$ & 53 & $32.32 \%$ \\
\hline $11-15$ & 20 & $12.20 \%$ \\
\hline
\end{tabular}

\begin{tabular}{|l|c|c|}
\hline Table 1: Cont'd. & $\begin{array}{c}\text { Response } \\
\text { Count }\end{array}$ & $\begin{array}{c}\text { Response } \\
\text { Percent }\end{array}$ \\
\hline $16-20$ & 7 & $4.27 \%$ \\
\hline $21-25$ & 3 & $1.83 \%$ \\
\hline $26-30$ & 3 & $1.83 \%$ \\
\hline $31-35$ & 0 & $0.00 \%$ \\
\hline $36-40$ & 1 & $0.61 \%$ \\
\hline $41-45$ & 1 & $0.61 \%$ \\
\hline $46-50$ & 0 & $0.00 \%$ \\
\hline $51-55$ & 1 & $0.61 \%$ \\
\hline $56-60$ & 1 & $0.61 \%$ \\
\hline$>60$ years & 4 & $2.44 \%$ \\
\hline Answered question & 164 & \\
\hline Skipped question & 6 & \\
\hline Level of Education & $\begin{array}{l}\text { Response } \\
\text { Count }\end{array}$ & $\begin{array}{l}\text { Response } \\
\text { Percent }\end{array}$ \\
\hline Doctorate degree & 6 & $3.64 \%$ \\
\hline Master degree & 8 & $4.85 \%$ \\
\hline Bachelor Degree & 126 & $76.36 \%$ \\
\hline Diploma & 16 & $9.70 \%$ \\
\hline High school & 8 & $4.85 \%$ \\
\hline Intermediate School & 0 & $0.00 \%$ \\
\hline Primary School & 1 & $0.61 \%$ \\
\hline Not educated & 0 & $0.00 \%$ \\
\hline Answered question & 5 & \\
\hline Skipped question & & \\
\hline & & \\
\hline
\end{tabular}

\begin{tabular}{|c|c|c|}
\hline Answer Options & $\begin{array}{l}\text { Response } \\
\text { Count }\end{array}$ & $\begin{array}{l}\text { Response } \\
\text { Percent }\end{array}$ \\
\hline Medication consultation & 89 & $55.28 \%$ \\
\hline Dispensing of prescribed medication & 119 & $73.91 \%$ \\
\hline Dispensing of over the counter medications & 88 & $54.66 \%$ \\
\hline Health information consultation & 59 & $36.65 \%$ \\
\hline Diseases consultations & 44 & $27.33 \%$ \\
\hline Dispensing of non-medications supplements & 74 & $45.96 \%$ \\
\hline Vaccines & 13 & $8.07 \%$ \\
\hline \multicolumn{2}{|l|}{ answered question } & 161 \\
\hline \multicolumn{2}{|l|}{ skipped question } & 9 \\
\hline
\end{tabular}

(Table 3). The most current experience of perception and challenges with high propriety scores were few pharmacist and clinical pharmacists, patient medication counseling privacy and unclear handwriting prescription. The most current expectations and perception with high propriety and opportunity scores were improve pharmacist communication skills and more information during patient analysis. The most future perception suggestion with high propriety 
and opportunity scores were increase awareness of pharmacist role in public health and implement pharmacy patient counseling clinic (Table 4).

\section{DISCUSSION}

The pharmacy strategic plan started with several pharmacy practices and clinical pharmacy programs. ${ }^{[8,9]}$ The pharmacy administration at Ministry of Health shared with other healthcare professionals in established evidence-based guidelines. The team consisted of physicians, nurses and pharmacists. The teams finished from several guidelines for instance but not limited to anticoagulation surgical prophylaxis in critically ill patients, anticoagulation surgical prophylaxis of

\begin{tabular}{|l|c|c|c|c|c|c|c|}
\hline \multicolumn{2}{|l|}{ Table 3: Pharmaceutical Care services levels provides to the patients. } \\
\hline Answer Options & Outstanding & Excellent & Neutral & Week & $\begin{array}{l}\text { Very } \\
\text { weak }\end{array}$ & $\begin{array}{l}\text { Rating } \\
\text { Average }\end{array}$ & $\begin{array}{l}\text { Response } \\
\text { Count }\end{array}$ \\
\hline $\begin{array}{l}\text { Pharmaceutical care services at MOH } \\
\text { hospitals }\end{array}$ & 11 & 54 & 79 & 14 & 9 & 3.26 & 167 \\
\hline $\begin{array}{l}\text { Pharmaceutical care services at non-MOH } \\
\text { governmental hospitals }\end{array}$ & 17 & 57 & 74 & 14 & 5 & 3.40 & 167 \\
\hline $\begin{array}{l}\text { Pharmaceutical care services at private } \\
\text { hospitals }\end{array}$ & 17 & 62 & 71 & 10 & 6 & 3.45 & 166 \\
\hline $\begin{array}{l}\text { Pharmaceutical care services at MOH } \\
\text { primary care centers }\end{array}$ & 12 & 31 & 74 & 38 & 12 & 2.96 & 167 \\
\hline $\begin{array}{l}\text { Pharmaceutical care services at privates } \\
\text { primary care centers }\end{array}$ & 8 & 37 & 89 & 26 & 7 & 3.08 & 167 \\
\hline $\begin{array}{l}\text { Pharmaceutical care services at community } \\
\text { pharmacies }\end{array}$ & 16 & 41 & 86 & 18 & 4 & 3.28 & 165 \\
\hline answered question & & & & & \\
\hline skipped question & & & & \\
\hline
\end{tabular}

\begin{tabular}{|c|c|c|c|c|c|c|c|c|}
\hline No & 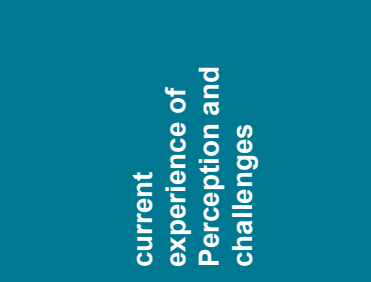 & 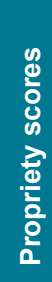 & 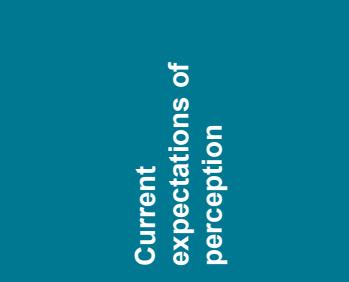 & 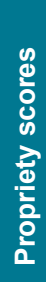 & 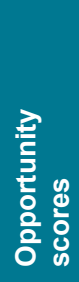 & 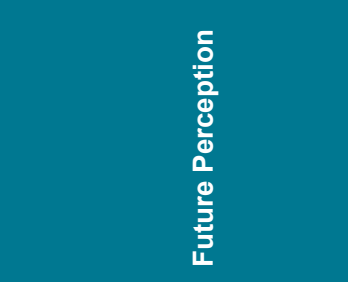 & 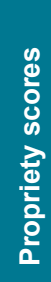 & 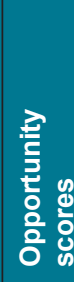 \\
\hline 1 & $\begin{array}{l}\text { few pharmacist and clinical } \\
\text { pharmacists, }\end{array}$ & 5 & $\begin{array}{l}\text { The pharmacist should be available } \\
\text { over } 24 / 7\end{array}$ & 5 & 4 & $\begin{array}{l}\text { Implement pharmacy patient } \\
\text { counseling clinic }\end{array}$ & 5 & 4 \\
\hline 2 & $\begin{array}{l}\text { patient medication counseling privacy } \\
\text { missed }\end{array}$ & 5 & $\begin{array}{l}\text { Improve pharmacist communication } \\
\text { skills. }\end{array}$ & 5 & 5 & Pharmacy home delivery & 4 & 4 \\
\hline 3 & Unclear handwriting prescription & 5 & More information in pharmacy label & 5 & 5 & Increase number clinical pharmacist & 5 & 4 \\
\hline 4 & Pharmacy not opening $24 \mathrm{~h}$ & 4 & $\begin{array}{l}\text { More information during patient } \\
\text { counseling }\end{array}$ & 5 & 5 & $\begin{array}{l}\text { More support of pharmaceutical } \\
\text { care services }\end{array}$ & 5 & 4 \\
\hline 5 & Pharmacy waiting for Ares small & 4 & $\begin{array}{l}\text { More authorization to reject } \\
\text { prescription if there are mistakes }\end{array}$ & 5 & 5 & $\begin{array}{l}\text { Increase awareness of pharmacist } \\
\text { role in public health }\end{array}$ & 5 & 5 \\
\hline 6 & $\begin{array}{l}\text { Some drug information question not } \\
\text { answered }\end{array}$ & 5 & $\begin{array}{l}\text { Pharmacy communication skills } \\
\text { training courses }\end{array}$ & 5 & 4 & & & \\
\hline 7 & $\begin{array}{l}\text { There is no limit time for preparation of } \\
\text { dispensing medication }\end{array}$ & 5 & $\begin{array}{l}\text { Pharmacy privatization during } \\
\text { patient counseling }\end{array}$ & 5 & 5 & & & \\
\hline 8 & & & Increase drug information resources & 5 & 4 & & & \\
\hline 9 & & & $\begin{array}{l}\text { Increase number of pharmacists } \\
\text { with emphasis on female gender }\end{array}$ & 5 & 4 & & & \\
\hline 10 & & & More fast of pharmacy services & 5 & 4 & & & \\
\hline 11 & & & $\begin{array}{l}\text { Use e-prescribing with clinical } \\
\text { altering system }\end{array}$ & 5 & 4 & & & \\
\hline \multirow[t]{3}{*}{12} & & & Saudization of pharmacist & 4 & 3 & & & \\
\hline & & & answered question & & & 80 & & \\
\hline & & & skipped question & & & 537 & & \\
\hline
\end{tabular}


extended travel and chronic illness. ${ }^{[10,11]}$ There were programs engrossed on cost-related issues, for instance, Pharmacoeconomics programs, a cost avoidance of medication error prevention, a cost avoidance of drug information centers, a cost avoidance of pharmacist intervention and cost also preventable of pharmacist running Total Parental Nutrition (TPN). ${ }^{[10-12]}$ The primary objective of the program was to recognize and prevent drug-related problems; through healthcare provider's awareness towards medications.

However, despite the collaboration between healthcare professionals and pharmacist still the perception of healthcare toward pharmacy services, their suggestions to reach the best pharmaceutical care are unknown in Kingdom of Saudi Arabia. The investigator aimed to identify the healthcare professionals' perception of pharmaceutical care service, challenges and development. The finding of the study showed that most of the pharmacy services had implemented the old concept of medications dispensing, over the counter distribution, non-medications items for dispensing and received by the healthcare professionals. Similar findings were reported by Merks $\mathrm{P}$ et al. as patient perception. [12] The new idea of pharmaceutical cares were not fully implemented and fully received by healthcare professionals for medications or disease consultation. These results are unanticipated because they should know the medications before usage. However, it is predictable to recommend the medications or use the medications without prescription particularly with over the counter (OTC) medications. The new system of immunization services distributed through the pharmacy had low perceptions. This is important finding. ${ }^{[12]}$ The system was not implemented yet because the system was not approved by Ministry of health. The healthcare professionals revealed that the good perception of pharmacy services through the hospital of privates or non-MOH governmental organizations. Most of the healthcare professionals' practice or often deal with it.

Two third of healthcare providers through drug information assumed to healthcare professionals is not satisfactory and be third of them does not have adequately of drug information knowledge. That is related to a week healthcare education from the pharmacy or the pharmaceutical services do comprise drug information services at the organization. Also, the inadequate knowledge of medication mostly ascribed to the lack of message from the medical practitioners due to the high patient load. The pharmacists in the pharmacy would assistance progress patients' knowledge of medication use. The healthcare provided clarified the reason for current experience with pharmacy services due to the shortage of pharmacist, clinical pharmacist and the pharmacy privacy and confidentiality. Also, the patient counseling program was not implemented for most organizations and using the old system of prescribing writing abides without using an electronic prescribing systems. Most of the healthcare organizations was not implemented patient education or utilization of computerized physician order entry system. The Healthcare professional knowledge about prescribed medication is a vital factor in decisive their compliance a patient and outcome of a disease. ${ }^{[11,12]}$ The healthcare providers can improve pharmacist communication skills with enough proving of medications knowledge and patient education about medications. The implementation of pharmaceutical care concept is highly challenging for healthcare professionals and drug information resources should be available to all healthcare providers. The healthcare professionals are increasingly recognized with high scores of proprieties and opportunities of pharmacy services to increase responsiveness of pharmacist role, to start the patient counselling clinic operated by pharmacist and usage medications home delivery.

All future suggestions can be applied through the general administration of pharmaceutical care at Ministry of Health, pharmacy scientific board, pharmacy professional's board at Saudi commissions of healthcare specialties and the pharmacy societies in Kingdom of Saudi Arabia.

\section{CONCLUSION}

The image and proficient performance of pharmacist at private sector are improving in Saudi Arabia. However, extra efforts should be rewarded to expand the clinical skills of the community pharmacists. The new concept of pharmaceutical care is extremely recommended to implement and expanded the pharmacy services at Kingdom of Saudi Arabia. They should play a hands-on role in becoming an effective and indispensable part of health care.

\section{ACKNOWLEDGEMENT}

None. 


\section{CONFLICT OF INTEREST}

The authors declare that there are no conflicts of interest.

\section{ABBREVIATIONS}

MEs: Medications Errors; MOH: Ministry of Health; OTC: Over the Counter; TPN: Total Parental Nutrition; KSA: Kingdom of Saudi Arabia.

\section{ORCID ID}

Yousef Ahmed Alomi (D, https://orcid.org/0000-00031381-628X

\section{REFERENCES}

1. Polgreen LA, Han J, Carter BL, Ardery GP. Collaboration intervention to improve blood. Hypertension. 2015;66(6):1145-51.

2. Farley TM. Physician-Pharmacist collaboration in a pay for performance healthcare environment. Bratisl Med J. 2015;116(9):517-9.

3. Ramser KL, Sprabery LR, George CM, Hamann GL, Vallejo VA, Dorko CS, et al. Physician-pharmacist collaboration in the management of patients with diabetes resistant to usual care. Diabetes Spectr. 2008;21(3):209-14.
4. Finkelstein RJ, Blaine ND, Parker CP. Summative evaluation of physicianpharmacist collaboration management. J Hypertens Open Access. 2016;5(2):1-7.

5. Hwang AY, Gums TH, Gums JG, Uni HP. The benefits of physicianpharmacist collaboration. J Fam Practice. 2017;66(12):1-8.

6. Oshima S, Senoo K, Negishi A, Akimoto H, Kutsuma N, Juni K, et al. Identification of the discrepancies between pharmacist and patient perception of the pharmacist's role as an advisor on drug therapy based on social science theory. Biol Pharm Bull. 2016;39(39):313-22.

7. Kelly DV, Bishop L, Young S, Hawboldt J, Phillips L, Keough TM. Pharmacist and physician views on collaborative practice: findings from the community pharmaceutical care project. Can Pharm J. 2013;146(4):218-26.

8. Alomi YA. National Pharmacy Practice Programs at Ministry of Health in Saudi Arabia. J Pharm Pharm Scien. 2015;1(2):17-8.

9. Alomi YA, Alghamdi SJ, Alattyh RA, Elshenawy RA. The Evaluation of Pharmacy Strategic Plan in Past 2013-2016 and Forecasting of New Vision 2030 at Ministry of Health in Saudi Arabia. J Pharm Pract Community Med. 2018;4(2):93-101.

10. Al-Hameed FM, Al-Dorzi HM, Abdelaal MA, Alaklabi A, Bakhsh E, Alomi YA, et al. The Saudi clinical practice guideline for the prophylaxis of venous thromboembolism in long-distance travelers. Saudi Med J. 2017;38(1):101-7.

11. Al-Hameed FM, Al-Dorzi HM, Abdelaal MA, Alaklabi A, Bakhsh E, Alomi YA, et al. The Saudi clinical practice guideline for the prophylaxis of venous thromboembolism in medical and critically ill patients. Saudi Med J. 2016;37(11):1279-93.

12. Merks P, Świeczkowski D, Jaguszewski MJ. Patients' perception of pharmaceutical services available in a community pharmacy among patients living in a rural area of the United Kingdom. Pharm Pract. 2016;14(3):774.

Cite this article as: Alomi YA, Aldosary BA, Al-Hathlool SA, Almulhim MI, Alashaq AA, Aboshalaf Y, Al-Ethan M. Attitudes and Perceptions of Healthcare Professionals towards Pharmaceutical Care Services in Kingdom of Saudi Arabia. Int J Pharmacol. Clin. Sci. 2019;8(2):110-5. 